\title{
NEKA PITANJA VEZANA UZ UPORABU I OSIGURANJE OSOBNIH MALIH ELEKTRIČNIH VOZILA
}

\author{
Mr. sc. Slaven Dobric** \\ Dr. sc. Jakša Filipović-Čugura** \\ Dr. sc. Marin Galić***
}

\author{
UDK 347.518:368.2 \\ https://doi.org/10.30925/zpfsr.42.1.11 \\ Ur.: 02. listopada 2020. \\ Pr.: 11. veljače 2021. \\ Pregledni rad
}

\begin{abstract}
Sažetak
Suvremeni život u urbanim sredinama ima mnoge pozitivne strane. No, suočava nas is brojnim izazovima, kao što su prometna zakrčenost i onečišćenje okoliša zbog povećane uporabe prometnih sredstava. U urbanim sredinama vožnja od samo nekoliko kilometara za vrijeme „prometnog čepa" traje znatno dulje od očekivanog. Zagreb ima i kronični problem nedostatka parkirnih mjesta u centru grada, kao i dostupnosti javnih garaža. Širenjem prometnica, uvođenjem novih pješačkih zona i izgradnjom interpolacija, broj parkirnih mjesta stalno se smanjuje. Usto, fiskalna politika Vlade u pogledu visokih trošarina na uvoz novih automobila poskupljuje nabavu novih vozila i kupce usmjerava prema starijim i rabljenim modelima. Novu vrstu mobilnosti u gradskim sredinama omogućuju mala električna vozila: električni romobil (e-romobil), Segway, hoverboard i električni skateboard (e-skateboard).
\end{abstract}

Ključne riječi: romobil; električni romobil; osiguranje električnog romobila; pravo osiguranja; ZOSPCN.

\section{UVODNO O PROBLEMU UPORABE I OSIGURANJU OSOBNIH MALIH ELEKTRIČNIH VOZILA U HRVATSKOJ}

Zakon o sigurnosti prometa na cestama ${ }^{1}$ romobile spominje $\mathrm{u}$ odredbi članka 124. stavka 2.: „Na kolniku je zabranjeno igranje, vožnja dječjim biciklom, romobilom i koturaljkama, kao i sanjkanje, skijanje i sl.“. Ta se odredba nalazi unutar glave 21. Kretanje pješaka, iz čega se zaključuje da se sudionik u prometu koji se vozi romobilom smatra pješakom, a ne vozačem.

* Mr. sc. Slaven Dobrić, član uprave Allianz Hrvatska d.d., Zagreb; Slaven.Dobric@allianz.hr. ORCID: https://orcid.org/0000-0002-5526-8472.

** Dr. sc. Jakša Filipović-Čugura, primarijus, KBC Sestre milosrdnice, Zagreb; jaksa@metromail. hr. ORCID: https://orcid.org/0000-0002-7125-7810.

*** Dr. sc. Marin Galić, poslijedoktorand, Fakultet političkih znanosti, Sveučilište u Zagrebu; marin.galic@fpzg.hr. ORCID: https://orcid.org/0000-0002-3009-1260.

1 Zakon o sigurnosti prometa na cestama pročišćeni tekst, Narodne novine, br. 67/08., 48/10., 74/11., 80/13., 158/13., 92/14., 64/15., 108/17., 70/19. i 42/20. (dalje: ZOSPCN). 
Nadalje, članak 2. stavak 1. točka 49. (pojmovi) istoga zakona bicikl definira kao „vozilo koje ima najmanje dva kotača i koje se pokreće isključivo snagom vozača ili koje je opremljeno pedalama i pomoćnim električnim motorom čija najveća trajna snaga nije veća od $0,25 \mathrm{~kW}$ i koja se progresivno smanjuje do nule kad brzina dostigne $25 \mathrm{~km} / \mathrm{h}$, ili prije, ako vozač prestane pokretati pedale“.

Iz toga slijedi da nema zakonske definicije električnoga romobila, niti se električni romobil može podvesti pod zakonski opis bicikla.

Već se u uvodu primjećuje da je ZOSPCN u tome dijelu zastario te da ne slijedi ubrzan tehnološki razvoj kojem svjedočimo posljednjih godina.

Radi jasnoće pojmova koji će se koristiti u ovome članku, navodimo nove vrste vozila koje su još uvijek neregulirane ili nedovoljno regulirane unutar zakonskoga okvira i koje je potrebno što prije zakonski regulirati (navedena klasifikacija preuzeta je od njemačkoga Saveznog ministarstva prometa i digitalne infrastrukture): ${ }^{2}$

- Osobna mala električna vozila (engl. Personal light electric vehicles, PLES): mala vozila pokretana električnim motorom, kao što su električni romobil, Segway, hoverboard i e-skateboard.

- Pedelec: vozila s pomoćnim električnim motorom čija se snaga progresivno smanjuje s porastom brzine. Od bicikla ih razlikuje upravo pomoćni električni motor koji pruža pomoć pri pedaliranju jer se aktivira samo kad vozač okreće pedale i podržava ga u upravljanju vozilom uz ograničenje brzine do $25 \mathrm{~km} / \mathrm{h} .^{3}$

- S-Pedelec: vozila s pomoćnim električnim motorom koja mogu postići brzinu do $45 \mathrm{~km} / \mathrm{h}$ te su time klasificirani kao mopedi.

U radu će se autori osvrnuti i na aktualno zakonsko uređenje osobnih malih električnih vozila (dalje: mala električna vozila), osobito na električne romobile. Dat će se prikaz i usporedba s njemačkom Uredbom o sudjelovanju malih električnih vozila u cestovnome prometu iz 2019. ${ }^{4}$ te s Novelom austrijskoga Zakona o cestovnome prometu iz 2019. ${ }^{5}$

U radu će se ukazati i na medicinski aspekt uporabe malih električnih vozila i navesti ozljede koje nastaju uporabom istih.

Predložit će se moguće rješenje zakonskoga reguliranja uporabe malih električnih vozila, koje se temelji na njemačkim i austrijskim zakonskim rješenjima, uz alternativno uvođenje fonda za naknadu štete prouzročene uporabom malih

2 Bundesministerium für Verkehr und digitale Infrastruktur, pristup 27. rujna 2020., https://www. bmvi.de/SharedDocs/DE/Artikel/StV/Strassenverkehr/elektrokleinstfahrzeuge-verordnungfaq.html.

3 ZOSPCN u odredbi članka 2. stavka 1., točke 49. bicikl definira upravo kao pedelec, pa je bicikl: ,vozilo koje ima najmanje dva kotača i koje se pokreće isključivo snagom vozača ili koje je opremljeno pedalama i pomoćnim električnim motorom čija najveća trajna snaga nije veća od $0,25 \mathrm{~kW}$ i koja se progresivno smanjuje do nule kad brzina dostigne $25 \mathrm{~km} / \mathrm{h}$, ili prije, ako vozač prestane pokretati pedale“.

4 Verordnung über die Teilnahme von Elektrokleinstfahrzeugen am Straßenverkehr (Elektrokleinstfahrzeuge-Verordnung - eKFV) (BGB1. I S. 756, od 6. lipnja 2019.) (dalje: eKFV).

5 Bundesgesetz, mit dem die Straßenverkehrsordnung 1960 geändert wird (32. StVONovelle), (BGB1. 77/2019, od 31. srpnja 2019.), (dalje: StVO). 
električnih vozila.

Prikazat će se pokrića uvjeta osiguranja privatne odgovornosti hrvatskih osiguravatelja te mogućnost naknade štete koju od malih električnih vozila pretrpe treće osobe.

Na samome početku istraživanja, postavljene su sljedeće teze:

1. Postojeće zakonsko uređenje u Republici Hrvatskoj ne odgovara potrebama za mobilnosti u prometu i tehnološkim rješenjima koja su dostupna na tržištu.

2. Sudionici u prometu koji upravljaju malim električnim vozilom ispravno su u ZOSPCN-u tretirani kao pješaci, te sukladno tomu odgovaraju po načelu subjektivne krivnje, jer se električni romobil ne može tretirati kao opasna stvar.

3. Ispravna je pretpostavka da se sudionici u prometu koji upravljaju malim električnim vozilom ne smiju koristiti kolnikom te da se smiju kretati samo po pločniku.

4. S obzirom na malu brzinu kretanja (do $20 \mathrm{~km} / \mathrm{h}$ ), malo električno vozilo ne predstavlja opasnost za druge sudionike u prometu te shodno tomu ne postoji potreba za obveznim osiguranjem malih električnih vozila. ${ }^{6}$

\section{MEDICINSKI ASPEKT UPORABE MALIH ELEKTRIČNIH VOZILA}

Promatrajući sve učestaliju uporabu malih električnih vozila s medicinskoga stanovišta, primjećuju se određene promjene koje se neosporno odražavaju i na rad osiguravajućih društava. Što je dakle posljedica sve većeg broja korisnika romobila, Segwaya, hoverboarda i e-skateboarda u prometu?

Uporaba tih vozila sve je učestalija kao alternativa automobilima, posebice u kontekstu prometnih gužvi i kroničnog nedostatka parkirnoga prostora. Prije su se električna vozila najčešće koristila u slobodno vrijeme, a sada je riječ o stalnim sudionicima prometa, i to bez osigurane pravne regulative. Svjetsko tržište brzo je preplavljeno velikim brojem modela koje koristi sve više ljudi. Lakoća uporabe i najma dovela je do eksponencijalnoga rasta prodaje, što je vidljivo iz analize Populus 2018 Groundtruth, ${ }^{7}$ koja potvrđuje rast prodaje električnih vozila u deset velikih gradova u SAD-u. Prodaja tih vozila porasla je od 52 do $79 \%$.

Učestalija uporaba električnih vozila donijela je u nekim gradovima određene restrikcije i zabrane. Uvodi se vremensko ograničenje korištenja, zabrana prometovanja određenim područjima, a u najekstremnijim slučajevima propisana je čak i potpuna zabrana korištenja električnih vozila (New York, Austin, London). ${ }^{8}$

6 Prvi je automobil konstruirao i izradio Carl Friedrich Benz, davne 1886. No, bilo je potrebno više od 30 godina da se uvede prvo pravo obvezno osiguranje, što je 1918. učinila Danska. Slijedile su je Švedska 1929. te Austrija i Ujedinjeno Kraljevstvo 1930. Marijan Ćurković, Obvezna osiguranja u prometu (Zagreb: Inženjerski biro, 2007.), 12-13.

7 Toshi Shepard-Ohta, „Populus groundtruth: data on the adoption of new mobility services“, SCAG Modeling Task Force, pristup 26. rujna 2018., https://scag.ca.gov/sites/main/files/fileattachments/mtf09262018_populusgroundtruth.pdf?1602913079.

8 Ministarstvo prometa Velike Britanije u dokumentu Powered transporters izrijekom navodi da je prometovanje malim električnim vozilima zabranjeno na nogostupu i biciklističkoj stazi. 
Električna vozila stvaraju percepciju ekološke osviještenosti vozača, ali unatoč načelno pozitivnom stavu javnosti, još uvijek je nejasno kojoj vrsti prijevoznih sredstava ta vozila pripadaju. Postavlja se i pitanje vozačke vještine i spremnosti korisnika na uključivanje $\mathrm{u}$ promet te utvrđivanja prometnih površina po kojima se električna vozila mogu kretati. Usluga najma električnih vozila otvara novu problematiku, od nebrige korisnika za tehničko stanje 'tuđe' imovine do nepropisne zaštite vozača.

Podatci američke Nacionalne udruge službenika gradskoga prijevoza iz 2018. navode da se na 100.000 vožnji električnih vozila događa 20 ozljeda. Objektivna medicinska literatura donosi brojne primjere medicinskih posljedica uporabe električnih vozila. ${ }^{9}$

Rad donosi zaključke istraživanja koje se fokusiralo na ozljede korisnika električnih vozila. Od 523 pacijenta koji su zaprimljeni u hitnu službu zbog prometnih nesreća u kojima su sudjelovala električna vozila, 249 osoba izravno je povezano s upotrebom e-skutera (engl. electric scooters), odnosno malih električnih vozila.

Od tih 249 ozljeda, zabilježena su natučenja (27,7\%), prijelomi $(40,2 \%)$ i ozljede glave (31,7\%). Prema mehanizmu ozljeđivanja, najveći udio zauzima pad vozača $(80,2 \%)$. Tek je mali broj njih pritom upotrebljavalo kacigu.

Istraživanja potvrđuju da sve učestalija uporaba malih električnih vozila rezultira većim brojem ozljeda. Tako američko Sveučilište Rutgers u svojim podatcima navodi da su ozljede lica i glave triput učestalije nego u prošlosti, a Medicinski centar Detroit bilježi četiri do pet puta više ozljeda uzrokovanih vožnjom malim električnim vozilima nego prije.

Već iz naslova rada The e-merging e-pidemic of e-scooters,${ }^{10}$ koji se također bavi tom problematikom, vidljivo je kakve posljedice za sobom povlači uporaba električnih vozila. Naglasak je na ozljedama glave i kosti koje su prisutne u više od $50 \%$ nastradalih. I u ovome se radu ističe da korisnici iznimno rijetko nose zaštitnu kacigu, a zabilježena je i učestalija konzumacija alkohola ${ }^{11}$ i drugih nedopuštenih

Dokument ostavlja mogućnost da ta vozila prometuju na kolniku, ali samo ako se ispune pretpostavke koje predviđaju posebni zakoni i koje između ostalog uključuju: osiguranje vozila, sukladnost tehničkim standardima, plaćanje poreza na motorna vozila, registracija, posjedovanje dozvola za upravljanje i zaštitne opreme. U dokumentu se navodi da vozač vjerojatno ne može ispuniti te pretpostavke te se ističe da je sudjelovanje u prometu na kolniku suprotno tim odredbama kazneno djelo, pristup 29. studenoga 2020., https://www.gov.uk/ government/publications/powered-transporters/information-sheet-guidance-on-poweredtransporters.

9 Tarak K. Trivedi, et al., „Injuries Associated With Standing Electric Scooter Use“, JAMA Network Open 2 (2019): e187381, pristup 25. siječnja 2019., https://jamanetwork.com/journals/ jamanetworkopen/fullarticle/2722574.

10 Leslie M. Kobayashi, et al., „The e-merging e-pidemic of e-scooters“, Trauma Surgery \& Acute Care Open, br. 4 (2019), pristup 29. studenoga. 2020., https://tsaco.bmj.com/content/4/1/ e000337.

11 „Prema podatcima njemačke policije, u prva tri mjeseca od stupanja na snagu i ozakonjenja uporabe malih električnih vozila zabilježene su 74 nezgode. Zanimljivo je da je u 65 slučajeva pokrenut prekršajni postupak zbog alkoholiziranosti vozača tih vozila." Marijan Ćurković i 
supstancija. ${ }^{12}$

Sve veći broj medicinskih radova, kao što je primjerice i istraživanje Numerical Investigation on Head and Brain Injuries Caused by Windshield Impact on Riders Using Electric Self-Balancing Scooters, opisuje vrste ozljeda i mehanizme ozljeđivanja. $^{13}$

Dakle, s medicinskoga stajališta, sve učestalija uporaba malih električnih vozila dovodi do znatnog povećanja broja prometnih nesreća, a u više od polovice slučajeva riječ je o teškim tjelesnim ozljedama.

Dodatni problem predstavlja nedostatak fizičkih dokaza prilikom očevida, jer mala električna vozila često nisu u vlasništvu vozača koji često i napušta prizorište nesreće, te nadležne službe ne mogu pronaći jasnu poveznicu između krivca i ozlijeđenog. Upitna je i tehnička ispravnost vozila, kao i vozačke vještine korisnika koji se upušta u promet, često bez ikakva iskustva i poznavanja osnovnih prometnih pravila. Situacija s malim električnim vozilima tipična je posljedica potrošačke prakse: prvo se lansira novi proizvod, njegova je uporaba sve učestalija i tek tada na red dolazi i legislativa. Upravo je zato što prije nužno zakonski regulirati uporabu malih električnih vozila u Republici Hrvatskoj.

\section{PRAVNO UREDENJE PROMETA MALIH ELEKTRIČNIH VOZILA U REPUBLICI HRVATSKOJ}

Sukladno s odredbom članka 2. stavka 1. točke 19 ZOSPCN-a, biciklistička staza je izgrađena prometna površina namijenjena za promet bicikala koja je odvojena od kolnika i obilježena propisanim prometnim znakom.

Prema odredbi članka 112. stavka 1. istoga zakona, vozači bicikla dužni su se kretati biciklističkom stazom ili biciklističkom trakom, a ako ih nema, što bliže desnom rubu kolnika.

Također, prema odredbi članka 124. stavka 3. istoga zakona, pješak se mora kretati nogostupom ili drugom površinom određenom za kretanje pješaka, odnosno površinom pokraj kolnika prikladnom za kretanje pješaka. U slučaju kršenja ove odredbe pješak će se kazniti novčanom kaznom u iznosu od 300,00 kuna, a sukladno s odredbom stavka 4. istoga članka.

Nadalje, članak 129. stavak 1. propisuje da je pješak dužan preko kolnika i

Šime Savić, „Električni romobili i slična vozila - sigurnosno-osigurateljni izazov“, Pravo $i$ porezi, br. 7 (2020): 46.

12 Nakon stupanja na snagu Uredbe, u Njemačkoj se mala električna vozila smatraju motornim vozilima, pa za njih vrijede pravila o vožnji pod utjecajem alkohola, kao i za ostala motorna vozila. Tako je odlukom Bavarskoga vrhovnog zemaljskog suda (BayObLG) od 24. srpnja 2020. potvrđena odluka kojom je 30-godišnjak kažnjen za upravljanje e-romobilom pod utjecajem alkohola. U krvi mu je izmjerena vrijednost od 1,35 promila. Izrečena mu je kazna od 2200 eura i zabrana upravljanja od tri mjeseca, pristup 30. studenog 2020., https://www. bussgeldprofi.de/magazin/e-scooter-pedelecs-und-alkohol.

13 Shi Shang, et al., Numerical Investigation on Head and Brain Injuries Caused by Windshield Impact on Riders Using Electric Self-Balancing Scooters (2018), pristup 29. studenoga 2020., https://doi.org/10.1155/2018/5738090. 
biciklističke staze ili trake prelaziti pažljivo i najkraćim putem, nakon što se prije stupanja na kolnik uvjeri da to može učiniti na siguran način. Ovdje valja napomenuti da će se sukladno odredbi članka 199. stavka 10, novčanom kaznom u iznosu od 500,00 kuna kazniti za prekršaj vozač bicikla i zaprežnog vozila ako u krvi ima alkohola iznad $0,50 \mathrm{~g} / \mathrm{kg}$, odnosno odgovarajući iznos miligrama u litri izdahnutog zraka ili ako je pod utjecajem droga ili lijekova.

Prema odredbama ZOSPCN-a vozač romobila izjednačen je s pješakom, to jest osobom koja sudjeluje u prometu, a nije vozač niti putnik u vozilu ili na vozilu. Suprotno tomu, vozač bicikla upravlja vozilom, pa tu dolazi do distinkcije između biciklista (koji sudjeluje u prometu kao vozač) i pješaka (koji, kao što smo vidjeli, nije vozač niti putnik u vozilu ili na vozilu).

ZOSPCN, kao ni bilo koji drugi propis, ne regulira status vozača romobila niti način njegova sudjelovanja u prometu.

S obzirom na to da nema zakonske regulative niti pravnog okvira, u praksi dolazi do dvojbe: kojim se površinama električni romobil smije kretati? Koja se pravila odnose na primjerice konzumaciju alkohola, nošenje zaštitne kacige, označavanje svjetlima ili reflektirajućim prslukom?

Zbog te zakonske praznine, ne možemo zaključiti ništa drugo nego da je električni romobil u zakonskome smislu i dalje samo romobil. To posljedično znači da je vozač romobila trenutno u Hrvatskoj izjednačen s pješakom i da se može kretati jedino nogostupom i da se pritom ne mora pridržavati odredbe o $0,50 \mathrm{~g} / \mathrm{kg}$ alkohola u krvi. Na njega se ne odnose ni druga zakonska (kaciga, dob, prsluk) ili tehnička ograničenja (svjetla), te se na romobilu može neograničeno prometovati po nogostupu.

Takav je zaključak nepovoljan za nezaštićene pješake i njihova prava kao najslabijih sudionika u prometu. Time se električnim romobilima u Republici Hrvatskoj omogućuje prometovanje bez ograničenja najveće snage i brzine te bez dobnog ograničenja vozača. Ne jamči se tehnička ispravnost električnih romobila jer uvoz tih vozila i njihovo stavljanje u promet ne podliježe bilo kakvoj vrsti sustavne kontrole. Štoviše, nisu propisani čak ni tehnički minimumi ispravnosti električnih romobila kao vozila uključenih u promet.

Usklađivanje propisa u Europskoj uniji u pravilu se razvija samo u smjeru ograničenja brzine na 20 ili $25 \mathrm{~km} / \mathrm{h}$ te snage na 250 ili $500 \mathrm{~W} \cdot{ }^{14}$ No, to nije danas slučaj i u Republici Hrvatskoj gdje ne postoji brzinsko ograničenje upravljanja električnim romobilom.

Izmjene ZOSPCN-a tijekom 2019. izazvale su niz rasprava o potrebi zakonskoga reguliranja uporabe električnih romobila u prometu. Nažalost, sve inicijative svele su se više-manje na priču o nepostojećoj Odluci Ustavnog suda kojom su se električni romobili izjednačili s pješacima. Na internetu je dostupno čak 5860 članaka elektroničkih medija s temom odluke Ustavnog suda o električnim

14 Maciej M. Sokolowski, „Laws and Policies on Electric Scooters in the European Union: A Ride to the Micromobility Directive?", European Energy and Environmental Law Review 29, br. 4 (2020): 127, pristup 29. studenog 2020., https://kluwerlawonline.com/journalarticle/ European+Energy+and+Environmental+Law+Review/29.4/EELR2020036. 
romobilima. ${ }^{15}$

Slijedom svega navedenog, očita je potreba da se pristupi reguliranju te zakonske praznine. Jedinice područne (regionalne) samouprave mogle bi svojim aktima regulirati uporabu električnih romobila na lokalnoj razini. ${ }^{16}$ Nažalost, nijedna jedinica područne (regionalne) samouprave dosad to nije učinila. ${ }^{17}$

Iako se ovaj rad bavi pravnim kontekstom i zakonskom regulativom uporabe električnih romobila, ta su vozila ipak samo jedna vrsta malih električnih vozila. Već smo prije spomenuli da istoj kategoriji pripadaju i Segway, hoverboard i e-skateboard. ZOSPCN ne spominje ni njih te ih ne možemo podvesti pod bicikle, romobile ili bilo koje drugo vozilo koje sudjeluje u prometu. Sva su ta vozila trenutačno u svojevrsnoj zakonskoj praznini jer njihovo sudjelovanje u prometu nije regulirano nikakvim propisima ili zakonskim aktima.

15 Tijekom 2019.umedijimajeobjavljenodajeUstavnisuddonio Odlukukojomje električniromobil proglasio pješakom. Međutim, niti jedna Odluka Ustavnog suda se nije do danas očitovala po tom pitanju.UpitprekotražiliceGoogle.hr23.siječnja2020.Rezultatiupitadostupnisuna:https://www. google.hr/search?sxsrf=ACYBGNSqVpZf_FIKMAGdT71PPQfcseJQJA\%3A1579776302079 \&source $=$ hp\&ei $=$ LnkpXv-HAuHGrgTMr7qYBQ\&q=odluka + ustavnog + suda $+o+$ elektri $\% C 4$ $\% 8$ Dnim+romobilima\&oq=odluka + ustavnog + suda + o+elektri\% $4 \% 8$ Dnim + romobilima\&gs

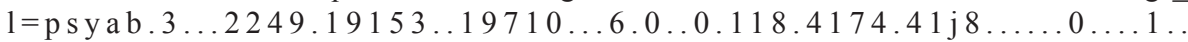
gwswiz....10..35i362i39j0j35i39j0i203j33i160j0i13j0i13i30j0i19j33i21. JbAVISwZTGw\&ved=0ahUKEwj_1rqqxZnnAhVho4sKHcyXDIMQ4dUDCAk\&uact=5\#spf $=1579776322212$.

16 Ustav Republike Hrvatske, Narodne novine, br. 56/90., 135/97., 8/98., 113/00., 124/00., 28/01., 41/01., 55/01., 76/10., 85/10., 5/14. (dalje: Ustav) u odredbi članka 129a propisuje poslove iz djelokruga jedinica područne (regionalne) samouprave pa izrijekom kaže (u stavku 2.) da te jedinice obavljaju poslove koje se odnose na promet. Zakon o lokalnoj i područnoj (regionalnoj) samoupravi, Narodne novine, br. 33/01., 60/0.1, 129/05., 109/07., 125/08., 36/09., 150/11., 144/12., 19/13. - pročišćeni tekst, 137/15. - ispravak, 123/17. i 98/1.9, (dalje: ZLPS) u Glavi III. Samoupravni djelokrug općine, grada i županije određuje u odredbi članka 19. stavka 1. podstavka 12. da općine i gradovi obavljaju poslove koji se odnose na promet na njihovu području. Nadalje, ZLPS u odredbi članka 19. stavka 2. određuje da će se posebnim zakonima odrediti poslovi čije su obavljanje općine i gradovi dužni organizirati te poslove koji mogu obavljati. ZOSPCN u Glavi II. Ovlaštenja za nadzor i uređenje prometa određuje u odredbi članka 5. stavka 1. da jedinica područne (regionalne) samouprave, u skladu s odredbama ZOSPCN-a i uz prethodnu suglasnost ministarstva nadležnog za unutarnje poslove, uređuje promet na svom području. To znači da su jedinice područne (regionalne) samouprave mogle primjerice urediti promet tako da zabrane kretanje električnih romobila po nogostupu ili u pješačkim zonama. Međutim, znamo da ZOSPCN nije definirao pojam električnoga romobila ni drugih vozila na električni pogon pa može biti upitno kako definirati električni romobil ili sankciju za njegovo prometovanje (s obzirom na to da definicija ne postoji ni u ZOSPCN-u). Autori unatoč tomu smatraju da su jedinice područne (regionalne) samouprave bile ovlaštene da to ipak učine na lokalnoj razini.

17 Primjerice, isto je učinila Metropolitanska policija u Londonu, kad je zabranila promet Segwayima, pristup 23. siječnja 2020., https://www.businessinsider.com/metropolitan-policewarn-hoverboards-illegal-london-2015-10?r=DE\&IR=T. 


\section{NJEMAČKO PRAVNO UREĐENJE PREMA ODREDBAMA EKFV-A}

Njemačka Uredba o sudjelovanju malih električnih vozila u cestovnome prometu (eKFV) objavljena je 14. lipnja 2019. u glasilu Bundesgesetzblatt ${ }^{18}$ a stupila je na snagu 15. lipnja 2019.

Zakonodavnu inicijativu pokrenuo je Klub zastupnika Zelenih. Oni su 8. lipnja 2018. njemačkoj Saveznoj vladi uputili upit. ${ }^{19}$ Klub zastupnika istaknuo je važnost malih električnih vozila za današnju mobilnost u prometu te Vladi postavio 25 pitanja.

Pritom je postavio i tvrdnju da je uporaba malih električnih vozila u Saveznoj Republici Njemačkoj je nezakonita i očekuje se da Vlada ima podatke o opsegu kažnjavanja korisnika tih vozila.

Vlada je očitovanjem od 27. lipnja $2018 .^{20}$ odgovorila na pitanja te je između ostalog istaknula da nema podatke o slučajevima prekršajnog postupka u cestovnom prometu, jer nadležna tijela saveznih država samostalno odlučuju o korištenju postojećeg osoblja i tehničkih pomagala za provođenje nadzornih mjera. ${ }^{21}$

Time nije osporila nezakonitost uporabe malih električnih vozila, ali je načine i opsege kažnjavanja prebacila na nadležna tijela saveznih država.

Unatoč nespremnosti prepoznavanja i praćenja trendova vezanih uz uporabu malih električnih vozila, nije trebalo dugo čekati na zakonodavni odgovor njemačke Vlade.

\subsection{Postupak donošenja Uredbe o sudjelovanju malih električnih vozila u cestovnome prometu (eKFV-a)}

Savezna vlada izradila je Uredbu kojom se uklanjaju pravne nesigurnosti u pogledu sudjelovanja električnih romobila u cestovnome prometu. Savezno vijeće odobrilo je prijedlog Uredbe 17. svibnja 2019., koja je stupila na snagu 15. lipnja 2019.

Prvi prijedlog Uredbe Ministarstva prometa i digitalne infrastrukture ${ }^{22}$ donesen je 21. rujna 2018. i predviđao je obvezno korištenje kacige te obveznu vozačku

18 Službeni glasnik Savezne Republike Njemačke.

19 Kleine Anfrage der Abgeordneten Matthias Gastel, Oliver Krischer, Daniela Wagner, Stefan Gelbhaar, Stephan Kühn (Dresden) und der Fraktion BÜNDNIS 90/DIE GRÜNEN, Drucksache 19/2620, 8. 6. 2018., pristup 23. siječnja 2020., http://dip21.bundestag.de/dip21/ btd/19/026/1902620.pdf.

20 Antwort der Bundesregierung auf die Kleine Anfrage der Abgeordneten Matthias Gastel, Oliver Krischer, Daniela Wagner, weiterer Abgeordneter und der Fraktion BÜNDNIS 90/ DIE GRÜNEN, Drucksache 19/3006, 27. 6. 2018., pristup 23. siječnja 2020., http://dip21. bundestag.de/dip21/btd/19/030/1903006.pdf.

21 Autori smatraju da su se takve odluke na sličan način mogle donijeti i u jedinicama područne (regionalne) samouprave u Republici Hrvatskoj.

22 BMVI, pristup 2. rujna 2020., https://www.bmvi.de/SharedDocs/DE/Anlage/Gesetze/ Gesetze-19/entwurf-verordnung-teilnahme-elektrokleinstfahrzeuge-strassenverkehr.pdf? blob=publicationFile. 
dozvolu kao pretpostavku za upravljanje malim električnim vozilima. Istim je aktom predviđena minimalna dob vozača koji može upravljati tim vozilima i iznosila je 16 godina, no prijedlog je u konačnici odbačen.

Navedeni prijedlog Uredbe izazvao je bijes korisnika malih električnih vozila: uslijedile su i optužbe da Savezna vlada ne djeluje u skladu sa zakonodavstvom Europske unije, te da će Njemačka biti jedina zemlja u Europi sa strogom regulativom uporabe malih električnih vozila. ${ }^{23}$

\section{2. Što pokriva Uredba o sudjelovanju malih električnih vozila $u$ cestovnome prometu?}

Sukladno s $\S 1$. Uredbe definirano je da malo električno vozilo pripada motornim vozilima, što je bila novina u njemačkome zakonodavstvu. Prema uredbi, malo električno vozilo sudjeluje u prometu kao i sva ostala motorna vozila.

Uredba je ujedno naznaka opasnosti koju mala električna vozila mogu biti za ostale sudionike u prometu te su navedenim aktom i de iure tretirana kao opasna stvar.

Ministarstvo prometa i digitalne infrastrukture objavilo je i tablični prikaz sustava:

\begin{tabular}{|l|l|l|l|l|}
\hline Gdje se može prometovati? & $\begin{array}{l}\text { Ograničenja vezana } \\
\text { uz dob }\end{array}$ & Brzina & Gdje & Kako \\
\hline Vozilo & $>14 \mathrm{~g}$. & $<20 \mathrm{~km} / \mathrm{h}$ & $\begin{array}{l}\text { Biciklistička } \\
\text { staza }\end{array}$ & $\begin{array}{l}\text { Obvezna kaciga i } \\
\text { osiguranje }\end{array}$ \\
\hline Bicikl & $\begin{array}{l}\text { Bez ograničenja } \\
\text { (osim djece) }\end{array}$ & $\begin{array}{l}\text { Neograničena } \\
\text { uporabom snage } \\
\text { mišića }\end{array}$ & $\begin{array}{l}\text { Biciklistička } \\
\text { staza }\end{array}$ & Preporučena kaciga \\
\hline S-Pedelec & $>16 \mathrm{~g}$. & $<45 \mathrm{~km} / \mathrm{h}$ & Kolnik & $\begin{array}{l}\text { Obvezna kaciga, } \\
\text { osiguranje i vozačka } \\
\text { dozvola }\end{array}$ \\
\hline
\end{tabular}

Tablica 1. Ograničenja vozača, brzine, kretanja i uvjeta malih električnih vozila. ${ }^{24}$

Istim § 1. utvrđeno je da se Uredba odnosi na mala električna vozila koja mogu postići brzinu od najmanje $6 \mathrm{~km} / \mathrm{h}$ do najviše $20 \mathrm{~km} / \mathrm{h}$.

Uredba se odnosi prvenstveno na e-romobile. Njome nisu obuhvaćena vozila poput hoverboarda i e-skateboarda.

23 „Stoga, zasada, stajalište EU-a je da e-bicikli, e-romobili i slična vozila ne trebaju biti u području primjene Direktive 2009/103.“Ćurković, Savić, Električni romobili i slična vozila, 45. To znači da mala električna vozila ne podliježu obvezi homologacije i registracije na području Europske unije, pristup 2. rujna 2019. https://www.elektro-skateboard.de/topic/6649-entwurf-einerverordnung-\%C3\%BCber-die-teilnahme-von-elektrokleinstfahrzeugen/

24 BMVI, Elektrokleinstfahrzeuge - Fragen und Antworten. Prikaz i prijevod autora, pristup 2. rujna 2020., https://www.bmvi.de/SharedDocs/DE/Artikel/StV/Strassenverkehr/ elektrokleinstfahrzeuge-verordnung-faq.html. 
U § 2. Uredba uvodi pravilo da u prometu može sudjelovati samo malo električno vozilo koje, između ostaloga, ima i valjanu naljepnicu osiguranja koja je predviđena za mala električna vozila (njem. Versicherungsplakette).

$\S 2$. Uredbe određuje da je minimalna starost za upravljanje tim vozilima 15 godina. Do te starosne granice nisu predviđene nikakve iznimke, niti je osim dobnoga ograničenja potrebno ispuniti neke druge uvjete za upravljanje, npr. Mofa certifikat. ${ }^{25}$

Od $\S 3$. do $\S 7$. Uredbe detaljno su opisane pretpostavke koje malo električno vozilo mora zadovoljiti u pogledu sustava kočenja (§ 3.), svjetla (§ 4.), zvona (§ 5.) i ostalih sigurnosnih elemenata.

Sukladno s § 8. Uredbom nije dopušten prijevoz osoba, ni vuča prikolice. To je izazvalo javnu raspravu, s obzirom na mogućnost uporabe malih električnih vozila $u$ dostavne svrhe (primjerice, u poštanskoj službi), gdje je prikolica pomoćno sredstvo.

\subsection{Sudjelovanje malih električnih vozila u cestovnome prometu}

Svatko tko upravlja malim električnim vozilom u prometu, dužan je pridržavati se odredbi prometnih propisa na način kako je propisano Uredbom.

Iako su mala električna vozila definirana kao motorna vozila, ona su u prometu zapravo tretirana kao bicikli. To znači da se vozači tih vozila prije svega trebaju kretati biciklističkim stazama ili biciklističkim trakama (§ 9. i 10.) ili prometovati na kolniku ako takve staze ne postoje. Važno je napomenuti da prema $\S 11$. stavku 4. Uredbe pješaci imaju prednost na zajedničkim pješačkim površinama koje dijele s vozačima tih vozila i ne smiju biti uznemiravani ili ugroženi od strane vozača. $\mathrm{U}$ slučaju potrebe, brzina kretanja malih električnih vozila mora biti usklađena $\mathrm{s}$ brzinom kretanja pješaka.

\subsection{Osiguranje malih električnih vozila i registarska oznaka}

U Uredbi je dodavanjem $\S 29$ a promijenjen i Fahrerlaubnis-Verordnung, ${ }^{26}$ postupak dobivanja vozačke dozvole za upravljanje tim vozilima. Istim se aktom određuje da mala električna vozila u prometu moraju imati Versicherungsplakette, odnosno oznaku osiguranja. Ta oznaka osiguranja potvrđuje da vozilo ima valjano osiguranje koje odgovara obveznom osiguranju potrebnom za sudjelovanje u prometu.

Ta oznaka osiguranja mora biti postavljena na stražnjem dijelu vozila, što je moguće bliže stražnjem svjetlu. Ako je osigurateljni odnos prestao prije isteka osiguranja navedenog na oznaci osiguranja, vlasnik vozila mora odmah ukloniti oznaku osiguranja i bez odgađanja je vratiti osiguratelju. U slučaju da to propusti učiniti, osiguratelj će o tomu obavijestiti nadležno tijelo koje će ukloniti oznaku osiguranja.

25 Mofa certifikat je dozvola za vožnju mopedima na dva i tri kotača i motornim vozilima koja razvijaju brzinu do $25 \mathrm{~km} / \mathrm{h}$.

26 Fahrerlaubnis-Verordnung, BGB1. I S. 1980, 13. 12. 2010. U slobodnom prijevodu autora: Regulacija dozvole za upravljanje. 
Osiguravajuća društva ovlaštena su izdavati oznaku osiguranja u skladu sa Zakonom o obveznim osiguranjima (njem. Pflicht-versicherungsgesetzes).

Uredba ništa ne govori o postupanju i pokriću u slučaju neosiguranog električnog vozila.

\subsection{Aktivnosti njemačkih osiguratelja nakon što je Uredba o sudjelovanju malih električnih vozila u cestovnome prometu stupila na snagu}

Nije trebalo dugo čekati na reakciju njemačkih osiguratelja nakon promjene zakonskog okruženja.

U nastavku se nalaze ponude osiguratelja Huk-Coburg i Allianz.

Huk-Coburg je najveći njemački osiguratelj motornih vozila. Na svojim internetskim stranicama nude osiguranje e-romobila koje iznosi 7,5 eura godišnje (riječ je o 2019.). ${ }^{27}$ Iznos premije osiguranja ovisi o starosti vozača (manje ili više od 23 godine), svoti osiguranja i datumu početka osiguranja. Naime, razdoblje važenja osiguranja odgovara osigurateljnoj godini te uvijek započinje 1. ožujka, a završava 28. ili 29. veljače sljedeće godine.

Svota obveznog osiguranja od odgovornosti iznosi 100 milijuna eura za štete na stvarima te 15 milijuna eura za štete na osobama, po osobi.

Uz obvezno osiguranje moguće je ugovoriti i kasko-zaštitu za pokriće šteta na samom vozilu (e-romobilu), u slučaju krađe, razbojstva ili požara, uz franšizu (sudjelovanje osiguranika u šteti od 150 eura).

Nakon zaključenja obveznog osiguranja, osiguranik dobiva oznaku osiguranja koju je dužan samostalno zalijepiti na e-romobil prije uključenja u promet.

Allianz ${ }^{28}$ također nudi obvezna osiguranja za e-romobile, uvodeći pritom i proširena kasko-pokrića u slučaju krađe, požara i eksplozije, prirodnih nepogoda, štete od ugriza životinja i sudara s divljim jelenima, konjima, kravama i ovnovima. Ta kasko-osiguranja pokrivaju i zamjenu ključa nakon gubitka, štetu od kratkoga spoja te zamjensku vrijednost novoga e-romobila u slučaju totalne štete ili krađe vozila.

Ne postoji osigurateljno pokriće u slučaju vožnje pod utjecajem alkohola, sudjelovanja na utrkama ili namjernog uništenja vozila od strane treće osobe. Također, izrijekom se navodi da polica osiguranja ne pokriva vandalizam.

Važno je napomenuti da osiguranje nije moguće mijenjati tijekom razdoblja

27 HUK-Coburg, pristup 24. studenoga 2019., https://www.huk.de/fahrzeuge/kfz-versicherung/ elektro-kleinstfahrzeuge.html.

28 Allianz, pristup 24. studenoga 2019., https://www.allianz.de/auto/e-scooterversicherung/?AZMEDID=SEM_SE-GG_VT-g_PR-KFZ.Elektrokleinfahrz euge_KA-16.ekf.b.escooter_AG-ekf.b.scooter.bmm_KW-\%2Ballianz\%20 $\% 2$ Bversicherung $\% 20 \% 2 \mathrm{Be} \% 20 \% 2 \mathrm{Bscooter}$ MT-b_Anzeige-354045674075_SLkeinSL_EG-c_PS-1t1\&ef_id=CjwKCAiA8ejuBRAaEiwAn-iJ31ddR_zR-vXaO_ KiMRUQ6OL 4 LWvtw1B21DiXVNLHbc66btuNdtQixoCy4UQAvD_BwE:G:s\&s_ kwcid $=$ AL! 8161 !3!354045674075!b!!g!!\%2Ballianz\%20\%2Bversicherung\%20 $\% 2 \mathrm{Be} \% 20 \% 2 \mathrm{Bscooter \& gclid=CjwKCAiA} 8$ ejuBRAaEiwAn-iJ3lddR_zR-vXaO_ KiMRUQ6OL4LWvtwlB21-DiXVNLHbc66btuNdtQixoCy4UQAvD_BwE\#produkt. 
osiguranja, to je moguće učiniti tek po isteku osigurateljne godine, odnosno od 1. ožujka sljedeće godine.

\subsection{Primjer sudske prakse u Saveznoj Republici Njemačkoj u odnosu na odgovornost korisnika malih električnih vozila prema pješacima}

Viši sud u Koblenzu potvrdio je 16. travnja 2019. (Az. 12 U 692/18) presudu

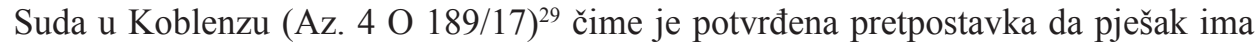
apsolutnu prednost $\mathrm{u}$ odnosu na mala električna vozila koja se kreću po zajedničkoj pješačkoj i biciklističkoj stazi.

U predmetnom slučaju pješak se nije zaustavio unatoč upozoravajućim signalima maloga električnog vozila, no stajalište suda bilo je da je vozač maloga električnog vozila trebao reagirati i odmah se zaustaviti. Pješak je na zajedničkoj stazi fotografirao i u jednome je trenutku krenuo unatrag. No, sud je naveo da pješaci imaju apsolutnu prednost u odnosu na mala električna vozila i nisu dužni stalno oko sebe pratiti što se događa na stazi kojom se kreću i drugi sudionici u prometu kojima je to dopušteno. Pješaci se mogu pouzdati u činjenicu da se drugi sudionici u prometu brinu o tome, te da prilagođavaju svoju brzinu i kretanje na zajedničkoj stazi. Kako sud navodi, ako pješak ne obraća pažnju ili ne reagira na upozoravajuće signale, vozilo se mora zaustaviti, ako je to jedini način da se izbjegne nesreća i da se pješak ne dovede $u$ opasnost.

Iz presude je vidljivo da je objektivna odgovornost na imatelju opasne stvari te da čak ni lakomislene radnje pješaka ne dovode do njegova oslobođenja od odgovornosti i umanjenja njegove odgovornosti. Vozač maloga električnog vozila smatra se sudionikom u prometu, a ne pješakom, te se tako treba utvrđivati i njegova odgovornost.

Također je razvidno da se malo električno vozilo tretira kao motorno vozilo u prometu, a ne kao pješak (kako se unutar zakonskoga okvira u Republici Hrvatskoj tretira korisnik e-romobila).

\section{AUSTRIJSKO PRAVNO UREĐENJE PREMA ODREDBAMA STVO-A}

Austrija je 1. lipnja 2019. Saveznim zakonom o izmjenama i dopunama Zakona o cestovnom prometu iz 1960. regulirala prometovanje malih električnih vozila.

To je rješenje uvedeno bez posebnoga propisa te krajnje jednostavno. Naime, $u$ postojeći Zakon dodan je izmjenama i dopunama samo § 88b, koji u pet (5) stavaka određuje pravila o uporabi malih električnih vozila u Austriji.

Savezni zakon o izmjenama i dopunama u § 88b uvodi pojam Rollerfahren, odnosno vožnju skuterom, a u odredbi toga članka govori o Klein- und Minirollern, odnosno o malim i miniskuterima (na električni pogon). Sukladno tomu, dalje će se

29 VR Daubner, pristup 3. studenoga 2019., https://daubner-verkehrsrecht.info/2019/unfallzwischen-segway-fahrerin-und-fussgaenger. Vozači Segwaya moraju biti obzirni prema pješacima. 
u tekstu, u dijelu koji se tiče austrijskoga primjera, to vozilo imenovati kao električni skuter.

Opće je pravilo, određeno tim Zakonom, da se električnim skuterom nije dopušteno kretati po pločniku ili biciklističkoj stazi. Iznimno se dopušta kretanje po pločniku, ali samo u slučajevima kad je to odobreno posebnom odlukom. No i tada skuter mora imati određena ograničenja. Dopuštena je snaga od najviše $600 \mathrm{~W}$ i brzina od najviše $25 \mathrm{~km} / \mathrm{h}$. Također, električnim je skuterima dopuštena vožnja i na biciklističkim stazama.

Stavak 2. uvodi obvezu upravljanja skuterima sukladno svim pravilima koja se odnose i na bicikle. To se odnosi i na način i smjer kretanja skutera.

Korisnici električnih skutera moraju se ponašati tako da ne ugrožavaju i ne ometaju ostale sudionike u prometu, a posebno moraju voditi računa o tome da brzinu kretanja prilagode pješačkom prometu u pješačkim zonama, u stambenim ulicama i na pješačkim prijelazima.

Djeca mlađa od 12 godina smiju koristiti električne skutere na javnim površinama, osim u stambenim ulicama, ali samo pod nadzorom osobe koja je navršila 16 godina, ako nemaju biciklističku dozvolu.

Električni skuteri moraju biti opremljeni učinkovitim sustavom kočenja, s reflektorima ili reflektirajućim folijama u bijeloj, crvenoj (straga) i žutoj (bočno) boji, a u mraku i u uvjetima loše vidljivosti skuter mora imati uključena prednja bijela i crvena stražnja svjetla.

Austrijski primjer pokazuje kako se jednostavno i brzo može regulirati prometovanje malih električnih vozila. Za razliku od njemačkoga primjera, austrijsko rješenje ne uvodi obvezu homologacije ni obvezno osiguranje malih električnih vozila. Austrijsko rješenje zahtijeva da električni skuteri moraju biti opremljeni učinkovitim uređajem za kočenje te uočljivim svjetlima, no ne propisuje daljnje tehničke pretpostavke, koje bi možda mogle biti i opravdane.

Postojećim električnim skuterima tim se rješenjem omogućuje da nastave prometovati, a njihove se vlasnike ne obvezuje na registraciju ili osiguranje za štete od odgovornosti prema trećim osobama.

Riječ je o primjerenoj kombinaciji prihvaćanja novih mobilnih okolnosti i prijevoznih sredstava te uređenja sudjelovanja električnih skutera u prometu.

\section{OSIGURANJE MALIH ELEKTRIČNIH VOZILA HRVATSKIH OSIGURATELJA}

Hrvatski osiguratelji postavili su se suzdržano u pogledu osiguranja malih električnih vozila. Nijedna osigurateljska tvrtka ne nudi osiguranje od odgovornosti za štete koje trećim osobama može nanijeti vozač maloga električnog vozila. Također, nijedan osiguratelj nije ponudio kasko-osiguranje za mala električna vozila, koje bi pokrilo njihovu krađu ili oštećenje.

Osiguratelji u uvjetima privatne odgovornosti ne isključuju pokriće za privatnu odgovornost koja bi mogla nastati uporabom malih električnih vozila. Nejasnim odredbama ostavljena je mogućnost da ti uvjeti pokrivaju i odgovornost iz vlasništva 
ili uporabe malih električnih vozila.

Predmet istraživanja autora bili su uvjeti osiguranja sljedećih osiguravajućih društava: Croatia osiguranje d.d., ${ }^{30}$ Allianz Hrvatska d.d. ${ }^{31}$ te Euroherc osiguranje d.d. ${ }^{32}$

Uvjeti za osiguranje od privatne odgovornosti Croatia osiguranja od 1. prosinca 2007. u 10 članaka definiraju pokriće osiguranja od privatne odgovornosti.

Članak 1. definira predmet osiguranja kao odgovornost osiguranika za štete koje prouzroči iz posjedovanja i uporabe bicikla bez motora. Pritom nije sporno da malo električno vozilo nije bicikl, kao što nije sporno ni da to vozilo posjeduje i elektromotor.

U članku 2. stavku 1. točki 2. navode se rizici koji su isključeni iz osiguranja: odgovornost za štete iz držanja i uporabe motornih vozila i drugih vozila na motorni pogon (traktora, motokultivatora, samohodnih radnih strojeva) te letjelica i plovila.

Nedoumica osiguranika tiče se činjenice da uvjeti Croatia osiguranja izrijekom navode traktore, motokultivatore i samohodne radne strojeve, ne navodeći ih samo primjera radi. To otvara i mjesta tumačenjima da bi mala električna vozila i štete iz njihove uporabe ili vlasništva ipak bile pokrivene uvjetima privatne odgovornosti.

Allianz Hrvatska uredilo je privatnu odgovornost Uvjetima za osiguranje od privatne odgovornosti, broj 150-0218 od 15. veljače 2018. Ti su uvjeti nešto opsežniji, ali sadržajno slični uvjetima Croatia osiguranja.

Tako se u članku 3. stavku 1. točki 4. kao predmet osiguranja navodi i građanskopravna izvanugovorna odgovornost osiguranika, za štetu zbog smrti, ozljede tijela ili zdravlja te oštećenja ili uništenja stvari treće osobe iz posjedovanja i uporabe bicikla bez motora.

Prema odredbama iz članka 6. stavka 1 . točke 3 . iz osiguranja su isključene štete iz posjedovanja i uporabe motornih i drugih vozila koja moraju biti registrirana prema pozitivnim zakonskim propisima.

Budući da mala električna vozila ne moraju biti registrirana prema važećim zakonskim propisima, otvara se mogućnost da štete nastale iz posjedovanja ili uporabe malih električnih vozila budu prema Uvjetima osiguranja Allianz Hrvatska u pokriću (s obzirom na to da su pokrivene sve štete u svojstvu privatne osobe u svakodnevnom životu, pa tako i pri uporabi ili vlasništvu maloga električnog vozila).

Euroherc osiguranje uredilo je privatnu odgovornost Uvjetima za osiguranje od odgovornosti koji su stupili na snagu 13. travnja 2018. Sadržajno bitno slični

30 Croatia osiguranje: Uvjeti za osiguranje od privatne odgovornosti, pristup 2. veljače 2020., https://www.crosig.hr/media/uvjeti_za_osiguranje_od_privatne_odgovornosti.pdf.

31 Allianz Hrvatska, Uvjeti za osiguranje od privatne odgovornosti, pristup 11. siječnja 2021., https://www.allianz.hr/content/dam/onemarketing/cee/azhr/privatni/hr/files/pdfs/docfinder/ dom-i-odgovornost/osiguranje-od-privatne-odgovornosti/T8373-05_Uvjeti_za_osiguranje od_privatne_odgovornosti_150-0218_WEB.pdf.

32 Euroherc osiguranje: Uvjeti za osiguranje od privatne odgovornosti, pristup 7. veljače 2020., https://www.google.com/url?sa=t\&rct=j\&q=\&esrc=s\&source=web\&cd=1\&cad=rja\&uact=8\& ved $=2$ ahUKEwi_keSO5cLnAhUKqIsKHeQeC9QQFjAAegQIBBAB\&url=https $\% 3 \mathrm{~A} \% 2 \mathrm{~F} \% 2 \mathrm{~F}$ www.euroherc.hr\%2Fdocuments\%2FUvjeti-za-osiguranje-od-odgovornosti.pdf\&usg=AOvVa w3j6Y_saVh_19wJr3oEw2BR. 
prethodno opisanim uvjetima drugih osiguratelja, definiraju predmet osiguranja kao građanskopravnu izvanugovornu odgovornost osiguranika, to jest osoba za koje on odgovara i ostalih članova njegovog kućanstva u svojstvu privatne osobe u svakodnevnom životu i to, između ostalog, iz vlasništva i uporabe bicikla bez motora.

U članku B.14 (Isključenja iz osiguranja) navodi se da se osiguranjem ne nadoknađuju štete počinjene iz vlasništva ili uporabe kopnenih motornih vozila, samohodnih radnih strojeva, traktora, motokultivatora i drugih sličnih strojeva za koje postoji obveza kada mogu biti pokriveni policom automobilske odgovornosti.

Euroherc je u svojim uvjetima dodao proširenje „i drugih sličnih strojeva“, kojima pripadaju i mala električna vozila, ali za koje postoji obveza kada mogu biti pokriveni policom automobilske odgovornosti.

Kako nema mogućnosti da se policom automobilske odgovornosti pokrije obveza nastala uporabom ili vlasništvom maloga električnog vozila, može se zaključiti da su ovim uvjetima u pokriću i štete nastale iz uporabe ili vlasništva maloga električnog vozila.

Radi pravne sigurnosti osiguranika, bilo bi svrsishodno da se odredbama uvjeta osiguranja od privatne odgovornosti nedvojbeno utvrdi kako su njima pokrivene i odgovornosti nastale iz uporabe ili vlasništva malih električnih vozila. Prema trenutačnom stanju, nijedan od analiziranih uvjeta osiguranja izrijekom ne pokriva štete nastale uporabom maloga električnog vozila. Ipak, definicije su nejasne pa se može zaključiti da nijedan od analiziranih uvjeta izrijekom ne isključuje te štete.

\section{RJEŠENJE DE LEGE FERENDA}

Iz analize je razvidno da u hrvatskome pravnom poretku postoji legislativna praznina. To je dovelo do situacije da se mala električna vozila tretiraju kao romobil, a vozač malog električnog vozila kao pješak, iako nije riječ o ravnopravnim sudionicima u prometu.

Nužno je što prije pravno regulirati sudjelovanje malih električnih vozila u prometu, pri čemu bi se trebalo voditi sljedećim postulatima:

- Mala električna vozila sve se više koriste u prometu, a uporaba tih vozila uvjetovana je tehnološkim razvojem i potrebom za većom mobilnosti u gradskim sredinama.

- Treba uvažiti sve učestaliju uporabu malih električnih vozila i zakonski regulirati njihovo sudjelovanje u prometu.

- Nužno je voditi se pravima i zaštitom najslabijih sudionika u prometu pješaka.

- Nužno je uzeti u obzir stanje prometne infrastrukture i prometnu kulturu građana Republike Hrvatske.

Postavlja se pitanje na koji je način najbolje regulirati status malih električnih vozila i ozakoniti njihovu uporabu, odnosno njihovo sudjelovanje u prometu. Autori predlažu dva niza rješenja:

- donošenje lex specialis ili izmjene i dopune ZOSPCN-a i 
- uvođenje obveznog osiguranja od odgovornosti za štete trećim osobama nastale zbog uporabe malih električnih vozila.

Ćurković i Savić smatraju da je prometovanje malih električnih vozila moguće regulirati posebnim propisom, kao u Njemačkoj, ili izmjenama i dopunama ZOSPCN-a uz izmjene i dopune Zakona o obveznim osiguranjima u prometu, ${ }^{33}$ ali svakako uz obvezu sklapanja ugovora o osiguranju od odgovornosti za štete koje vlasnik/korisnik tim vozilom prouzroči trećim osobama. ${ }^{34}$

Uvođenje obveznog osiguranja malih električnih vozila zagovaraju i Ćurković i Baričević. ${ }^{35}$

Obvezna osiguranja uvode i formiranje fonda za neosigurana i nepoznata vozila, koja predstavljaju veliki problem u Republici Hrvatskoj. Pitanje je što bi donijelo obvezno osiguranje malih električnih vozila i znači li to da bi sva ta vozila u Republici Hrvatskoj morala biti automatski osigurana? Čak i uz osiguranje prijelaznoga razdoblja, vjerojatno bi mnoga mala električna vozila ostala neosigurana.

Obvezno osiguranje definiralo bi i dodatnu obvezu vlasnika malih električnih vozila. Time bi se također otvorilo i pitanje reguliranja privremenoga prometovanja malih električnih vozila tijekom turističke sezone. Hoćemo li ih kažnjavati, isključivati iz prometa $\mathrm{i}$ za štete od takvih neosiguranih vozila teretiti garancijski fond?

Kao što smo vidjeli, u Republici Austriji postoji mogućnost da se sudjelovanje u prometu malih električnih vozila uredi i bez uvođenja obveznog osiguranja. Također, taj nas primjer navodi na zaključak da je moguće vrlo učinkovito (a time vjerojatno i brzo) legalizirati mala električna vozila putem izmjena i dopuna postojećih propisa.

Nužno je definirati i na koji način mala električna vozila postaju sudionici u prometu te utvrditi njihov odnos prema ostalim sudionicima, prvenstveno prema pješacima, ali i biciklistima.

Slijedom iznesenoga predlaže se legaliziranje malih električnih vozila po uzoru na austrijski primjer, $\mathrm{i}$ to:

Izmjenama i dopunama ZOSPCN-a, tako da se u pojmovima (članak 2.) definira pojam maloga električnog vozila kao vozila maksimalne snage elektromotora do 500 W i brzine kretanja najviše do $25 \mathrm{~km} / \mathrm{h}$. Nadalje, potrebno je definirati prometovanje malih električnih vozila tako da u prometu sudjeluju na isti način kao i bicikli (članak 112.), odnosno da se kreću prvenstveno biciklističkom stazom i biciklističkom trakom, ili što bliže desnom rubu kolnika ako ne postoje navedene staze i prometne površine. To znači da mala električna vozila ne bi smjela prometovati po nogostupu.

33 Zakon o obveznim osiguranjima u prometu, Narodne novine, br. 151/05., 36/09., 75/09., 76/13. i $152 / 14$.

34 Ćurković i Savić, Električni romobili i slična vozila, 47.

35 Marijan Ćurković i Hrvoje Baričević, „Njemačko pravno uređenje može biti dobar putokaz“, Revija HAK, 302-303, kolovoz-rujan 2020., 28. Autori iznose mišljenje da su električni romobili vozila koja se u određenim okolnostima uporabe smatraju opasnom stvari, poglavito u srazu s pješacima. Nadalje, zagovaraju reguliranje prometovanja e-romobila i uvođenje obveznog osiguranja, prema njemačkome modelu. 
Također, bit će potrebno urediti propise o svjetlima, kočionim sustavima i ostalim tehničkim karakteristikama vozila, u svemu bitno sličnome kao i za bicikle.

Bez uvođenja obveznog osiguranja od odgovornosti za štetu koju vlasnik/ korisnik tim vozilom prouzroči trećim osobama.

\section{FOND ZA NAKNADU ŠTETE PROUZROČENE MALIM ELEKTRIČNIM VOZILIMA}

Naplata štete koju uzrokuju vozači malih električnih vozila još je uvijek neriješeno pitanje. Nesreće i sudari s pješacima ponekad uzrokuju teške ozljede koje iziskuju dugotrajno liječenje i oporavak, uz opasnost od trajnih zdravstvenih posljedica.

U pogledu naknade štete najjednostavnije je preslikati njemački prijedlog rješenja koji svakog vlasnika maloga električnog vozila obvezuje na sklapanje obveznog osiguranja. Pitanje je može li se u Hrvatskoj takav zakon doista provesti u djelo, uzmemo li u obzir da je čak i u jednoj uređenoj državi kao što je Njemačka primjena zakona naišla na prijepor? Obvezno osiguranje automatski podrazumijeva i tehničku ispravnost vozila, a tehnička ispravnost zahtijeva redoviti pregled i kontrolu.

Pitanje je tko bi i kako kontrolirao valjanost osiguranja? Znači li to da bi policija mogla zaustaviti korisnike malih električnih vozila i provjeravati posjeduju li obvezno osiguranje? Takav je scenarij malo vjerojatan u praksi i stoga je u Republici Hrvatskoj moguće pronaći drugo rješenje.

Moguće rješenje jest naplata štete iz fonda za štete nastalih uporabom malih električnih vozila. Najvažnije je odrediti kako što pravednije puniti taj fond, odnosno regulirati da ga pune korisnici malih električnih vozila, a ne i drugi građani. Učinkovito rješenje mogla bi biti direktna uplata $u$ fond prilikom kupnje maloga električnog vozila. To znači da bi se određeni postotak od prodajne cijene malih električnih vozila automatski preusmjeravao $u$ fond za naplatu šteta koje ta vozila uzrokuju.

Takvo rješenje nije potpuna novina u hrvatskim zakonima i možemo ga donekle usporediti sa sustavom naknada za privatno kopiranje autorskih djela. Zakonom o autorskom pravu i srodnim pravima ${ }^{36}$ uvedeno je pravo na naknadu za reproduciranje (umnožavanje) autorskog djela za privatno ili drugo vlastito korištenje - takozvani sustav privatnog kopiranja. Riječ je o izuzeću od isključivog prava autora da odobri ili zabrani svako umnožavanje svojeg djela, te se njime građanima omogućuje da s legalnoga izvora za svoje privatne i osobne potrebe umnožavaju autorska djela. Po tom sustavu, autori za djela za koja se, s obzirom na njihovu prirodu, može očekivati da će bez njihova odobrenja biti reproducirana (kopirana, umnožena) snimanjem na nosače zvuka, slike ili teksta za privatno ${ }^{37}$ ili drugo vlastito korištenje, imaju pravo

36 Zakon o autorskom pravu i srodnim pravima, Narodne novine, br. 167/03., 79/07., 80/11., 141/13., 127/14., 62/17., 96/18.

37 Korisnici su uz određene uvjete ovlašteni kopirati djela za svoje privatno i nekomercijalno korištenje. Iznimka privatnog kopiranja smatra se nužnom kako bi se interesi nositelja prava 
na odgovarajuću naknadu. Ta naknada određuje se za proizvode tehničkih uređaja za tonsko ili vizualno snimanje i prazne nosače zvuka, slike ili teksta, a podmiruju je proizvođači takve opreme i uređaja odnosno njihovi uvoznici. ${ }^{38}$

U praksi, te naknade znače da cijena uređaja ili medija uključuje iznos ${ }^{39}$ koji se dodjeljuje autorima, izvođačima, proizvođačima fonograma i izdavačima, kao kompenzacija za privatno kopiranje njihovih djela. ${ }^{40}$

Slično bi se moglo primijeniti i na mala električna vozila, a osim pri samoj kupnji vozila, određeni prihodi mogli bi se ostvariti i prilikom kupnje rezervnih dijelova električnih vozila, prvenstveno baterija koje imaju vijek trajanja i koje čine najveći udio u ukupnoj cijeni malih električnih vozila. Postotak koji se uplaćuje $\mathrm{u}$ fond trebao bi se prilagoditi tako da ne predstavlja pretjerani financijski teret kupcima, ali da se pritom ipak prikupi dovoljna količina novca za isplatu šteta.

Postavlja se još jedno posve legitimno pitanje. Što ako se malo električno vozilo kupuje u inozemstvu? Rješenja nema, odnosno u toj situaciji gotovo je nemoguće zadovoljiti formu i preusmjeriti određeni iznos u fond. Upravo zato potrebno je optimizirati postotak koji se uplaćuje u fond, kako proizvod ne bi bio osjetno skuplji u Hrvatskoj nego u ostalim zemljama, pogotovo u državama Europske unije.

Osnivanje fonda za naplatu šteta prouzročenih malim električnim vozilima, koji bi se punio prilikom kupnje svih vrsta električnih vozila, mogući je način naplate šteta u Republici Hrvatskoj. Isto je načelo već djelotvorno u području zaštite autorskih prava, treba ga samo prilagoditi i primijeniti na mala električna vozila. Ipak, prije određivanja postotka (ili fiksnoga dijela cijene) potrebno je napraviti studiju koja bi pokazala očekivanu godišnju razinu šteta koje uzrokuju mala električna vozila, kako bi se shodno tomu odredila i novčana veličina fonda.

\section{ZAKLJUČ AK}

Nužno je pravno regulirati sudjelovanje u prometu malih električnih vozila. Dobrim zakonodavnim rješenjima dobit ćemo tehnički sigurna mala električna vozila i definirati javne površine i prometnice kojima mogu prometovati te time zaštititi i vozače tih vozila i najslabije sudionike u prometu - pješake.

Sukladno svemu iznesenome, nakon izvršene komparativne analize autori su došli do sljedećih zaključaka i odgovora:

uskladili s interesima korisnika te kako bi se pravo na određeni način pomirilo s društvenom stvarnošću u kojoj korisnici svakodnevno izrađuju takve kopije. S druge strane, nužno je kompenzirati nositelje prava za propuštenu dobit zbog privatnog kopiranja. Zbog toga je i uveden sustav naknada za privatno kopiranje. One su poštena novčana nadoknadu kojom se nositelje prava kompenzira kada se njihova djela kopiraju bez njihova pristanka i plaćanja.

38 ZAMP, pristup 29. studenoga 2019., https://www.zamp.hr/korisnici/pregled/64/98/privatnokopiranje.

39 Primjerice, prema važećem Cjeniku naknada za reproduciranje autorskih djela za privatnu ili drugu vlastitu uporabu koji je na snazi od 2015., one iznose 0,08 kuna za prazni CD odnosno 0,12 kuna za DVD, 3,00 kune za memorijsku karticu ili disk, 6,00 kuna za osobno računalo, 10,00 kuna za tablet ili 14,00 kuna za digitalni audio player.

40 EUIPO, pristup 29. studenoga 2019., https://euipo.europa.eu/ohimportal/hr/web/observatory/ faqs-on-copyright-hr. 
1. Postojeći zakonski okvir Republike Hrvatske ne odgovara aktualnim potrebama mobilnosti njezinih građana i tehnološkim rješenjima koja su u vidu malih električnih vozila dostupna na tržištu.

2. Sudionici u prometu koji upravljaju malim električnim vozilima neispravno su unutar ZOSPCN-a tretirani kao pješaci. Vozač maloga električnog vozila treba imati zakonsku odgovornost kao imatelj opasne stvari.

3. Sudionici u prometu koji upravljaju malim električnim vozilima trebali bi se za kretanje koristiti prvenstveno biciklističkim stazama i kolnikom.

4. Ozljede u prometu nastale uporabom malih električnih vozila navode na razmatranje uvođenja obveznog osiguranja ili drugoga oblika zaštite oštećenika u prometu (primjerice, osnivanjem fonda za naplatu šteta). Ipak, autori smatraju da uvođenje obveznog osiguranja nije potrebno, te predlažu pravno uređenje prometovanja malih električnih vozila kao u Austriji.

Četvrto pitanje može se riješiti na dva načina. U ovome smo radu analizirali oba postojeća rješenja: njemačko i austrijsko. Iako je njemačko rješenje temeljitije (uvođenje obveznog osiguranja), u obzir se moraju uzeti svi čimbenici i sagledati sve pravne posljedice donošenja takve odluke, posebno imajući u vidu troškove koje takva odluka može izazvati.

Nadalje, otvara se pitanje je li malo električno vozilo opasna stvar ili ga se može tretirati kao bicikl? Sudskom praksom već je utvrđeno da se bicikl u prometu ne smatra opasnom stvari. ${ }^{41}$ Trebamo li onda malo električno vozilo smatrati opasnom stvari ili ne? Autori smatraju da definicija električnog vozila kao opasne stvari ovisi o kontekstu i okolnostima te da se mora promatrati zasebno, od slučaja do slučaja: malo električno vozilo koje se kreće brzinom od $25 \mathrm{~km} / \mathrm{h}$ u pješačkoj zoni može biti opasna stvar. Čak i u slučaju manje dopuštene maksimalne brzine, prioritet treba biti zaštita najslabijih sudionika u prometu - pješaka.

Nadalje, iako nije bio neposredan predmet ovog rada mora se voditi računa i o definiranju pravne situacije sa S-Pedelecima. To su vozila s pomoćnim električnim motorom koja kombiniranjem fizičke snage vozača i snage pomoćnoga motora mogu postići brzinu do $45 \mathrm{~km} / \mathrm{h}$, te su time klasificirani kao mopedi. I ZOSPCN ih tako definira, ali još uvijek ne postoje provedbeni akti ni pretpostavke za registraciju tih vozila u Republici Hrvatskoj. Zbog toga, iako je danas fokus javnosti na malim električnim vozilima, potrebno bi bilo iskoristiti izmjene ZOSPCN da se u cijelosti uredi i status $S$-Pedeleca.

\section{Knjige i članci}

\section{LITERATURA}

1. Ćurković, Marijan. Obvezna osiguranja u prometu. Zagreb: Inženjerski biro, 2007.

2. Ćurković, Marijan i Hrvoje Baričević. „Njemačko pravno uređenje može biti dobar putokaz“. Revija HAK, 302-303 kolovoz-rujan (2020): 28-29.

3. Ćurković, Marijan i Šime Savić. „Električni romobili i slična vozila - sigurnosnoosigurateljni izazov“. Pravo i porezi, br. 7 (2020: 44-47).

41 Županijski sud u Splitu, Gžp-1187/2010 od 24. ožujka 2011.: „U rješenju drugostupanjski sud je prvostupanjskom sudu ukazao na činjenicu da motorno vozilo u pokretu predstavlja opasnu stvar, dok bicikli u prometu (i inače) ne predstavljaju opasnu stvar“. 
4. Kobayashi, Leslie M., Elliot Williams, Carlos V. Brown, Brent J. Emigh, Vishal Bansal, Jayraan Badiee, Kayle D. Checchi, Edward M. Castilo i Jay. Doucet. „The e-merging e-pidemic of e-scooters". Trauma Surgery \& Acute Care Open, br. 1 (2019): 1-5. https:// tsaco.bmj.com/content/4/1/e000337.

5. Shang, Shi, Yanting Zheng, Ming Shen, Xianfeng Yang i Jun Su. „Numerical Investigation on Head and Brain Injuries Caused by Windshield Impact on Riders Using Electric Self-Balancing Scooters". Applied Bionics and Biomechanics, (2018): 1-15, Article ID 5738090, https://doi.org/10.1155/2018/5738090.

6. Shepard-Ohta, Toshi. „Populus groundtruth: data on the adoption of new mobility services“. SCAG Modeling Task Force. Pristup 26. rujna 2018. http://www.scag.ca.gov/ committees/CommitteeDocLibrary/mtf09262018_PopulusGroundtruth.pdf.

7. Sokolowski, Maciej M. „Laws and Policies on Electric Scooters in the European Union: A Ride to the Micromobility Directive?". European Energy and Environmental Law Review 29, br. 4 (2020): 127-140, https://kluwerlawonline.com/journalarticle/ European+Energy+and+Environmental+Law+Review /29.4/EELR2020036.

8. Trivedi, Tarak K., Charles Liu, Anna Liza M. Antonio, Natasha Wheaton, Vanessa Kreger, Anna Yap, David Schriger i Joan G. Elmore. „Injuries Associated With Standing Electric Scooter Use“. JAMA Network Open 2, br. 1 (2019): 1-9. Pristup 25. siječnja 2019. https://jamanetwork.com/journals/jamanetworkopen/fullarticle/2722574.

Pravni propisi i sudska praksa

1. Bundesgesetz, mit dem die Straßenverkehrsordnung 1960 geändert wird (32. StVONovelle), (BGBl. 77/2019, od 31. srpnja 2019.).

2. Das OLG Koblenz bestätigt am 16. 4. 2019, (Az. 12 U 692/18) das Urteil des LG Koblenz (Az. 4 O 189/17). https://daubner-verkehrsrecht.info/2019/unfall-zwischensegway-fahrerin-und-fussgaenger, Segway-Fahrerin muss auf Fußgänger Rücksicht nehmen.

3. Ustav Republike Hrvatske, Narodne novine, br. 56/90., 135/97., 8/98., 113/00., 124/00., 28/01., 41/01., 55/01., 76/10., 85/10., 05/14.

4. Verordnung über die Teilnahme von Elektrokleinstfahrzeugen am Straßenverkehr (Elektrokleinstfahrzeuge-Verordnung - eKFV) (BGBl. I S. 756, od 6. lipnja 2019.).

5. Zakon o autorskom pravu i srodnim pravima, Narodne novine, br. 167/03., 79/07., 80/11., 141/13., 127/14., 62/17., 96/18.

6. Zakon o lokalnoj i područnoj (regionalnoj) samoupravi, Narodne novine, br. 33/01., 60/01., 129/05., 109/07., 125/08., 36/09., 150/11., 144/12., 19/13. - pročišćeni tekst, 137/15. - ispravak, 123/17. i 98/19.

7. Zakon o sigurnosti prometa na cestama, pročišćeni tekst, Narodne novine, br. 67/08., 48/10., 74/11., 80/13., 158/13., 92/14., 64/15., 108/17. i 70/19.

8. Županijski sud u Splitu, Gžp-1187/2010 od 24. ožujka 2011.

\section{Internetski izvori}

1. Allianz Hrvatska: Uvjeti za osiguranje od privatne odgovornosti. Pristup 7. veljače 2020. https://www.allianz.hr/media/1656328/t8373-05_uvjeti_za-osiguranje_od_privatneodgovornosti_150-0218_web.pdf.

2. Allianz. Pristup 24. studenoga 2019. https://www.allianz.de/auto/e-scooterversicherung/?AZMEDID=SEM_SE-GG_VT-g_PR-KFZ.Elektrokleinfahrzeuge KA-16.ekf.b.escooter_AG-ekf.b.scooter.bmm_KW-\%2Ballianz\%20 $\% 2$ Bversicherung $\% 20 \% 2 \mathrm{Be} \% 20 \% 2 \mathrm{Bscooter}$ MT-b_Anzeige-354045674075_SLkeinSL_EG-c_PS-1t1\&ef_id=CjwKCAiA8ejuBRAaEiwAn-iJ31ddR_zR-vXaO KiMRUQ60L-4LWvtwlB21DiXVNLHbc66btuNdtQixoCy4UQAvD_BwE:G:s\&s_ 
kwcid=AL! $8161 ! 3 ! 354045674075$ !b!!g!!\%2Ballianz\%20\%2Bversicherung\%20 $\% 2 \mathrm{Be} \% 20 \% 2 \mathrm{Bscooter} \&$ gclid=CjwKCAiA8 8 juBRAaEiwAn-iJ3lddR_zR-vXaO_ KiMRUQ6OL4LWvtwlB2l-DiXVNLHbc66btuNdtQixoCy4UQAvD_BwE\#produkt.

3. BMVI, Elektrokleinstfahrzeuge - Fragen und Antworten. Pristup 24. studenoga 2019. https://www.bmvi.de/SharedDocs/DE/Artikel/StV/Strassenverkehr/ elektrokleinstfahrzeuge-verordnung-faq.html.

4. Bundesministerium für verkehr und digitale infrastruktur. Pristup 27. rujna 2020. https:// www.bmvi.de/SharedDocs/DE/Artikel/StV/Strassenverkehr/elektrokleinstfahrzeugeverordnung-faq.html.

5. Croatia osiguranje: Uvjeti za osiguranje od privatne odgovornosti. Pristup 2. veljače 2020. https://www.crosig.hr/media/uvjeti_za_osiguranje_od_privatne_odgovornosti.pdf.

6. EUIPO. Pristup 29. studenoga 2019. https://euipo.europa.eu/ohimportal/hr/web/ observatory/faqs-on-copyright-hr.

7. Euroherc osiguranje: Uvjeti za osiguranje od privatne odgovornosti. Pristup 7. veljače 2020. https://www.google.com/url?sa=t\&rct=j\&q=\&esrc=s\&source $=$ web \&cd $=1 \& \mathrm{cad}=\mathrm{rja} \& u a c t=8 \& \mathrm{ved}=2$ ahUKEwi_keSO5cLnAhUKqIsKHe Qe C 9 Q QFjA A e g Q IB B A B \& url=https\%3 A\%2F\%2Fwww.euroherc. hr\%2Fdocuments\%2FUvjeti-za-osiguranje-od-odgovornosti.pdf\&usg=AOvVaw3j6Y saVh $19 \mathrm{wJ} 3 \mathrm{oEw} 2 \mathrm{BR}$.

8. HUK-Coburg. Pristup 24. studenoga 2019. https://www.huk.de/fahrzeuge/kfzversicherung/elektro-kleinstfahrzeuge.html.

9. ZAMP. Pristup 29. studenoga 2019. https://www.zamp.hr/korisnici/pregled/64/98/ privatno-kopiranje. 


\author{
Slaven Dobrić* \\ Jakša Filipović-Čugura** \\ Marin Galić***
}

\begin{abstract}
Summary
SOME QUESTIONS REGARDING USAGE AND INSURANCE OF PERSONAL LIGHT ELECTRIC VEHICLES
\end{abstract}

Contemporary life in urban areas, in addition to many positive aspects, has also brought traffic congestion and heavy pollution caused by use of means of transport. In urban areas, driving a few kilometres during a "traffic jam" takes much longer than expected. In Zagreb, there is also an enduring lack of parking slots in the city centre, as well as the lack of availability of public garages. With the expansion of roads and introduction of new pedestrian zones, as well as construction of interpolations, the number of parking slots is constantly decreasing. In addition, Governmental fiscal policy of high import duties on new cars significantly increases the cost of vehicles and directs buyers towards older used models.

New mobility is achieved through personal light electric vehicles: e-scooters, Segway, hoverboards and e-skateboards.

Keywords: light electric vehicles; e-scooters; electric scooter insurance; right to insurance.

* Slaven Dobrić, mr. sc. Board member, Allianz Hrvatska d.d., Zagreb; Slaven.Dobric@allianz. hr. ORCID: https://orcid.org/0000-0002-5526-8472.

** Jakša Filipović-Čugura, Ph.D., Primarius, Sestre milosrdnice University Hospital Center, Zagreb; jaksa@metromail.hr. ORCID: https://orcid.org/0000-0002-7125-7810.

*** Marin Galić, Ph.D., Postdoctoral researcher, Faculty of Political Science, University of Zagreb; marin.galic@fpzg.hr. ORCID: https://orcid.org/0000-0002-3009-1260. 